\title{
Decreased Stimulatory Guanosine Triphosphate Binding Protein in Dogs with Pressure-Overload Left Ventricular Failure
}

\author{
J. Peter Longabaugh, ${ }^{\star}$ Dorothy E. Vatner, ${ }^{\star \ddagger}$ Stephen F. Vatner, ${ }^{\star}$ and Charles J. Homcy* \\ ${ }^{*}$ Harvard Medical School and the Cardiac Unit, Massachusetts General Hospital, Boston, Massachusetts 02114; and ${ }^{\ddagger}$ Harvard Medical \\ School and New England Regional Primate Center, Southboro, Massachusetts 01772
}

\begin{abstract}
Alterations in the level and function of the stimulatory guanyl nucleotide binding protein $\left(G_{s}\right)$ from the cardiac sarcolemma were examined in a canine model of heart failure. The present study is based on our previous investigations that demonstrated both a loss of $\beta$-adrenergic agonist high-affinity binding sites and a decreased adenylate cyclase activity in sarcolemma from failing hearts. Using cholera toxin and [ ${ }^{32}$ P]NAD, we labeled the alpha subunit of $G_{s}\left(G_{s \alpha}\right)$ and found a $59 \%$ reduction in the level of this protein. Further, a $50 \%$ reduction in $G_{s}$ activity was noted in a reconstitution assay utilizing membranes from the mouse $\mathbf{S} 49$ lymphoma cell line cyc-, which is deficient in $\mathbf{G}_{\mathbf{s}}$. These data suggest that, in this model of pressure-overload left ventricular failure, the acquired defect in the $\beta$-adrenergic receptor/adenylate cyclase system involves a deficiency in the coupling protein $G_{\mathbf{s}}$. Such an abnormality may explain the decreased adrenergic responsiveness of the failing left ventricle.
\end{abstract}

\section{Introduction}

The failing left ventricle (LV) ${ }^{1}$ depends on adrenergic stimulation for maintenance of the compensated state. Braunwald and co-workers demonstrated in animals that the failing left ventricle has decreased responsiveness to sympathetic nerve stimulation (1). They also demonstrated elevations in the levels of circulating catecholamines as well as depletion of tissue stores of norepinephrine (2). More recent studies have assessed the status of adrenergic receptors in failing myocardium, both in experimental animals $(3,4)$ and in man $(5)$. The present study identifies a defect distal to the receptor in the transduction of adrenergic signals to the heart in left ventricular failure.

The $\beta$-adrenergic receptor/adenylate cyclase system is a plasma membrane-bound protein assembly consisting of three major components: the $\beta$-adrenergic receptor, which binds hormone; the adenylate cyclase catalytic unit, which synthesizes cAMP from ATP; and the stimulatory guanyl nucleotide binding protein $\left(\mathrm{G}_{\mathrm{s}}{ }^{2}\right)$, which couples the receptor to

These data were presented in part at the national meeting of the American Heart Association on 17 November 1986.

Received for publication 21 July 1987.

1. Abbreviations used in this paper: $\mathrm{Gpp}(\mathrm{NH}) \mathrm{p}, 5^{\prime}$-guanylylimidodiphosphate; $G_{s}$, stimulatory guanyl nucleotide-binding protein; $G_{s \alpha}$, alpha subunit of $G_{s} ; L V$, left ventricle.

J. Clin. Invest.

(C) The American Society for Clinical Investigation, Inc.

$0021-9738 / 88 / 02 / 0420 / 05 \quad \$ 2.00$

Volume 81, February 1988, 420-424 adenylate cyclase $(6,7)$. Data from our laboratories suggest that alterations in adrenergic control of failing myocardium occur at many levels. In a canine model of LV failure induced by chronic pressure overload, the number of myocardial $\beta$ adrenergic receptors was found to increase $(4,8)$. Despite this increase, the number of high-affinity $\beta$-adrenergic agonist binding sites, which results from the coupling of agonist-occupied $\beta$-adrenergic receptor to $G_{s}(9)$, was reduced fourfold (4). The loss of high-affinity agonist binding sites suggests that there is a defect in the coupling of $\mathrm{G}_{\mathrm{s}}$ and $\beta$-adrenergic receptor. Further, the activity of adenylate cyclase was reduced by $>50 \%$ when stimulated by $\beta$-adrenergic receptor agonists or by agents that bypass the receptor and activate adenylate cyclase via $G_{s}$, e.g., sodium fluoride or 5'-guanylylimidodiphosphate (Gpp[NH]p), a nonhydrolyzable guanosine triphosphate analogue (4). This suggested the possibility of an abnormality in the coupling between $G_{s}$ and adenylate cyclase. This finding was specific to the hypertrophied, failing left ventricle; it was not observed in membranes prepared from the unaffected right ventricle. The present study was undertaken to further define potential abnormalities of $G_{s}$ in heart failure that would explain these observations. We report here that $\mathrm{G}_{\mathrm{s}}$ appears to be deficient or defective in sarcolemma from failing left ventricle as assessed by both cholera toxin labeling and reconstitution studies.

\section{Methods}

The animal model predominantly used in this study is described by Kleinman et al. (10), and has been utilized previously in our laboratories $(4,8)$. Mongrel puppies of either sex at $7-10 \mathrm{wk}$ of age underwent thoracotomy, and a teflon cuff was placed around the ascending aorta. After a period of 9 mo to $2 \mathrm{yr}$, during which the animals developed left ventricular hypertrophy, left ventricular failure ensued. Normal controls were either sham-operated or not operated. One adult animal underwent unilateral wrapping of a kidney and contralateral nephrectomy as described (11), resulting in the development of severe systemic hypertension, left ventricular hypertrophy, and then left ventricular failure. After the development of congestive heart failure, evidenced by elevated left ventricular end diastolic pressure $(>30 \mathrm{~mm} \mathrm{Hg})$, elevated mean left atrial pressure $(>20 \mathrm{~mm} \mathrm{Hg})$, and pulmonary edema, as indicated by rales on auscultation or pulmonary congestion at postmortem examination, the animals underwent hemodynamic studies as described $(4,8)$, and were sacrificed with an overdose of pentobarbital. All animals used in this study were maintained in accordance with the guidelines of the Harvard Medical School Committee on Animals and the Guide for the Care of Laboratory Animals (DHHS publication No. (NIH)85-23, revised 1985).

Membrane preparation. After sacrifice, cardiac sarcolemmal membranes from left ventricle and interventricular septum were prepared as previously described (8) using a modification of the method of Jones and Besch (12). Briefly, the hearts were excised and placed into KrebsRingers solution. Approximately $1 \mathrm{~mm}$ of epicardium and endocardium was removed with scissors and discarded. Left ventricular myocardium was homogenized and crude membranes were prepared by 
washing the homogenate in the buffers described except that $0.75 \mathrm{M}$ $\mathrm{NaCl}$ was used in the first buffer instead of $0.75 \mathrm{M} \mathrm{KCl}$. The sarcolemmal component was obtained by floating crude membranes through a sucrose density gradient. Membranes were quickly frozen in a dry ice-acetone bath and stored at $-70^{\circ} \mathrm{C}$ until further use.

Cholera toxin labeling. Quantitation of cholera toxin substrate was performed as previously described by our laboratory (13). Sarcolemmal membranes (10 $\mu \mathrm{g}$ membrane protein) were mixed with membranes prepared from a $\mathrm{G}_{3}$-deficient variant of the $\mathrm{S} 49$ mouse lymphoma cell line $c y c$ - (40 $\mu \mathrm{g}$ membrane protein) in $250 \mu$ lof buffer (100 $\mathrm{mM}$ Tris-HCl, $5 \mathrm{mM} \mathrm{MgCl}$, 1 mM EDTA, pH 7.4). Cyc- membranes were added to provide a source of ADP-ribosylation factor, which is necessary for the cholera toxin reaction but is absent from sarcolemmal membranes (13). $100 \mu \mathrm{l}$ of an assay buffer $(250 \mathrm{mM}$ potassium phosphate, pH 7.0, $40 \mathrm{mM}$ phosphocreatine, $20 \mathrm{mM}$ thymidine, 113 $\mathrm{U} / \mathrm{ml}$ creatine phosphokinase, $10 \mathrm{mM}$ ATP, $0.5 \mathrm{mM} \mathrm{GTP}$, and 2.5 mM NADP) was added to this. Activated cholera toxin $(1 \mathrm{mg} / \mathrm{ml})$ was prepared in a buffer of $50 \mathrm{mM}$ Hepes, $135 \mathrm{mM} \mathrm{NaCl}, 5 \mathrm{mM}$ dithio-

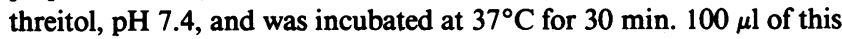
solution was added to the assay mixture and the reaction was initiated by adding $50 \mu$ lof $\left.{ }^{32} \mathrm{P}\right] \mathrm{NAD}(50 \mu \mathrm{M}, 10-50 \mathrm{Ci} / \mathrm{mmol})$. Reactions were carried out for $90 \mathrm{~min}$ and quenched by the addition of an equal volume of ice cold buffer ( $100 \mathrm{mM}$ Tris- $\mathrm{HCl}, \mathrm{pH} 7.4,5 \mathrm{mM} \mathrm{MgCl}$, and $1 \mathrm{mM}$ EDTA) containing $1 \mathrm{mM}$ NAD. Membranes were then pelleted and solubilized in sample buffer, and the constituent proteins were resolved on sodium dodecyl sulfate (SDS)-13\% polyacrylamide gels as described (13) using the method of Laemmli (14). A second assay was performed on each sample of sarcolemma using the same method except that cholera toxin was omitted from the reaction. Labeled bands were excised from the gel and counted. The corresponding region from lanes where cholera toxin was omitted was also cut out and counted to establish background. The molar amount of cholera toxin-specific incorporated label was calculated on the basis of specific activity of the [ $\left.{ }^{32} \mathrm{P}\right]$ NAD used in each experiment.

Reconstitution of $G_{s}$ into cyc- membranes. Using a method described by Sternweis and co-workers (15), cardiac sarcolemma (3 $\mathrm{mg} / \mathrm{ml}$ membrane protein) was solubilized in $2 \%$ sodium cholate (recrystallized from ethanol) in a buffer of $20 \mathrm{mM}$ Tris- $\mathrm{HCl}$ (pH 7.7), 1 mM EDTA, $1 \mathrm{mM}$ dithiothreitol for $1 \mathrm{~h}$ on ice. The supernatant from a $20,000 \mathrm{~g}$ spin was heated at $30^{\circ} \mathrm{C}$ for $10 \mathrm{~min}$ to inactivate the solubilized catalytic unit. The extract was then diluted into $0.1 \% \mathrm{Lu}-$ brol (in the same buffer), and $15 \mu \mathrm{l}$ was added to $25 \mu \mathrm{l}$ of $c y c$ - membranes (60 $\mu \mathrm{g}$ of membrane protein) and allowed to sit on ice for 30 min. Preactivation was then performed by adding $20 \mu \mathrm{l}$ of a buffer consisting of $125 \mathrm{mM}$ Hepes, $\mathrm{pH} 8.0,50 \mathrm{mM} \mathrm{MgCl} 2,2.5 \mathrm{mM} \mathrm{ATP}$, $500 \mu \mathrm{M}$ GTP, $1 \mathrm{mM}$ EDTA, $30 \mathrm{mM}$ phosphocreatine, $350 \mathrm{U} / \mathrm{ml}$ creatine phosphokinase, and $2.5 \mathrm{mM}$ cAMP, as well as $20 \mu \mathrm{l}$ of $40 \mathrm{mM}$ $\mathrm{NaF}$, and followed by incubation at $30^{\circ} \mathrm{C}$ for $20 \mathrm{~min}$. Adenylate cyclase activity was then assayed by adding $5 \times 10^{6} \mathrm{cpm}\left[\alpha^{32} \mathrm{P}\right] \mathrm{ATP}$ and $8 \times 10^{3} \mathrm{cpm}\left[{ }^{3} \mathrm{H}\right] \mathrm{cAMP}$ in $20 \mu \mathrm{l}$ and incubating for an additional 10 $\min$ at $30^{\circ} \mathrm{C}$. The reaction was terminated by the addition of $100 \mu \mathrm{l}$ of $2 \%$ SDS. After the addition of $800 \mu \mathrm{l}$ of $\mathrm{H}_{2} \mathrm{O}$, the amount of cAMP produced was determined as previously described (4). The synthesis of cAMP was linear with time up to $20 \mathrm{~min}$. The time required to attain maximum activity in the preactivation step was consistent with data published by Sternweis et al. (15).

$\mathrm{Na}^{+}, \mathrm{K}^{+}$-ATPase activity was determined according to the method of Jones and Besch (12). Protein concentrations were measured by the method of Lowry et al. (16), and $c y c$ - membranes were prepared according to Ross et al. (17). $\beta$-Adrenergic receptor binding studies were performed as previously described (4). Results were expressed as mean \pm SEM and were compared using the unpaired Student's $t$ test. Significance was defined as $P<0.05$.

\section{Results}

Characterization of the model. Table I demonstrates the hemodynamic and morphologic characteristics of our canine model.
Table I. Hemodynamic and Morphologic Characterization of the Model

\begin{tabular}{|c|c|c|}
\hline & Normal $(n=5)$ & Heart failure $(n=4)$ \\
\hline Body weight $(g)$ & $23 \pm 1.3$ & $23 \pm 2.0$ \\
\hline \multicolumn{3}{|l|}{ LV free wall/body } \\
\hline weight $(g / k g)$ & $3.43 \pm 0.7$ & $7.16 \pm 0.97^{*}$ \\
\hline \multicolumn{3}{|l|}{ LV systolic pressure } \\
\hline$(\mathrm{mm} \mathrm{Hg})$ & $132 \pm 3$ & $227 \pm 27^{*}$ \\
\hline \multicolumn{3}{|l|}{ LV end diastolic } \\
\hline pressure $(m m H g)$ & $6.9 \pm 0.7$ & $34 \pm 6.9^{*}$ \\
\hline \multicolumn{3}{|l|}{ Mean arterial pressure } \\
\hline$(m m H g)$ & $106 \pm 3$ & $109 \pm 11$ \\
\hline \multicolumn{3}{|l|}{ Heart rate } \\
\hline (beats/min) & $96 \pm 10$ & $148 \pm 15^{*}$ \\
\hline
\end{tabular}

$* P<0.01$.

Of note, the LV systolic pressures are significantly elevated $(P$ $<0.01)$ and the LV free wall-to-body weight ratio is doubled $(P<0.01)$ in the dogs with heart failure. The degree of left ventricular failure is demonstrated by the $\mathrm{LV}$ end diastolic pressure $(34.0 \pm 6.9 \mathrm{~mm} \mathrm{Hg}$ in failure vs. $6.9 \pm 0.7 \mathrm{~mm} \mathrm{Hg}$ in normals, $P<0.01)$. These data are consistent with our previously published results (4). Furthermore, biochemical characterizations of LV sarcolemmal membranes prepared from these animals agree with our previous findings. The $\beta$-adrenergic receptor density as demonstrated by antagonist binding studies with $\left[{ }^{125} \mathrm{I}\right]$ iodocyanopindolol was increased $(3.11 \pm 0.11$ $\mathrm{pmol} / \mathrm{mg}$ in $\mathrm{LV}$ failure, $n=4$, vs. $1.71 \pm 0.49 \mathrm{pmol} / \mathrm{mg}$ in normals, $n=5, P<0.03$ ). Finally, the purity of sarcolemmal membranes was assayed using $\mathrm{Na}^{+}, \mathrm{K}^{+}$-ATPase as an independent marker. There was no significant difference in the group with LV failure $(27.6 \pm 13.5 \mu \mathrm{mol} \mathrm{Pi} / \mathrm{h}$ per mg protein, $n=4)$ when compared with normal controls $(31.5 \pm 5.5 \mu \mathrm{mol} \mathrm{Pi} / \mathrm{h}$ per mg protein, $n=5$ ). In addition, there was no significant difference in the yield of sarcolemma per wet weight of left ventricular tissue (normal, $10.0 \pm 1.4 \mathrm{mg} / 100 \mathrm{~g}, n=5$; $\mathrm{LV}$ failure, $9.5 \pm 2.5 \mathrm{mg} / 100 \mathrm{~g}, n=4)$.

These data confirm that the animals used in this study are hemodynamically and biochemically similar to those reported previously by this laboratory. Also, because the yields of sarcolemma and the specific activity of $\mathrm{Na}^{+}, \mathrm{K}^{+}$-ATPase were not different, the differences observed in sarcolemma from normal and failing LV are not due to contaminants in the membrane preparations. This is further supported by the observation that $\beta$-adrenergic receptor density is increased in LV sarcolemma from animals with heart failure.

Cholera toxin $\left[{ }^{32} P\right] N A D$ quantitation of $G_{s}$. Cholera toxin transfers an ADP-ribose group from NAD to the alpha subunit of $G_{s}\left(G_{s \alpha}\right)(7,18)$. When $\left.{ }^{32} P\right] N A D$ is used as a substrate and the labeled components of the membrane preparation are resolved on SDS-polyacrylamide gels, $\mathrm{G}_{\mathrm{s} \alpha}$ can be identified by autoradiography. Because cholera toxin transfers only one ADP-ribose moiety to one $G_{s \alpha}(18)$, the labeled band containing $G_{s \alpha}$ can be excised from the gel and counted to assess the molar amount of this species. It should be noted that only one band of $45 \mathrm{kD}$ (Fig. 1, inset $A$, and reference 13) is labeled in canine cardiac sarcolemma, whereas in most tissues, a doublet of 45 and $52 \mathrm{kD}$ is seen. Validation of the cholera toxin label- 

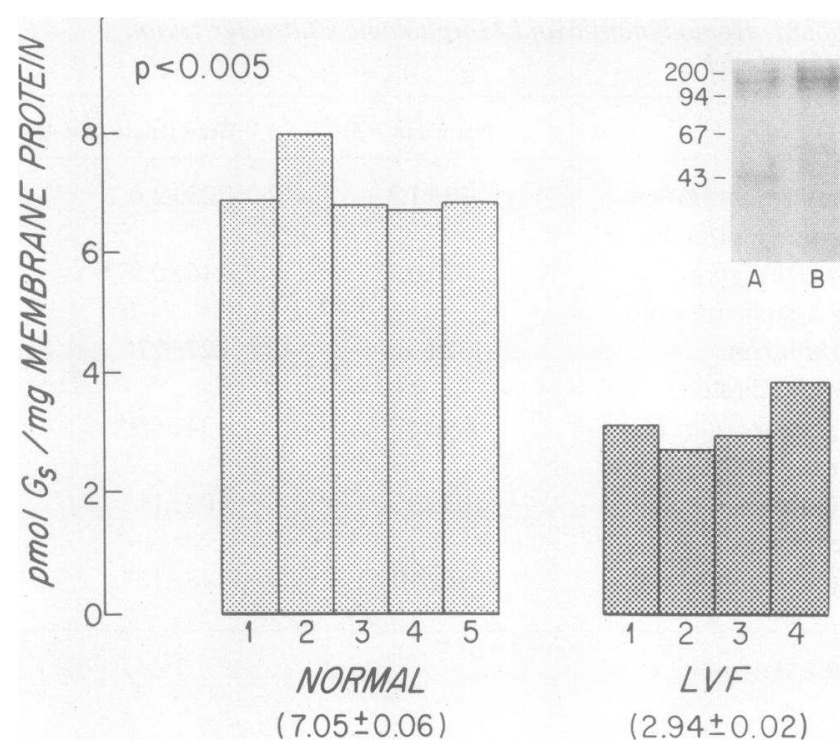

Figure 1. Cholera toxin labeling of sarcolemma prepared from normal and failing LV. Bars show average valves obtained from individual dogs from two experiments performed in duplicate. Saturation of $\mathrm{G}_{\mathbf{s}}$ labeling is shown in the inset. Equal amounts of sarcolemma were treated with cholera toxin as described in Methods except that in $A$ no NAD was included in the treatment, and in $B 5 \mu \mathrm{M}$ NAD (unlabeled) was used. After washing the samples three times, each was again treated with cholera toxin and $\left[{ }^{32} \mathrm{P}\right] \mathrm{NAD}$, exactly as described in Methods.

ing technique as a method of quantitating $\mathrm{G}_{\mathrm{s} \alpha}$ requires evidence that complete labeling of substrate has occurred. This was demonstrated by two techniques. First, under conditions where the $\left[{ }^{32} \mathrm{P}\right] N A D$ substrate was not limiting, incorporation of label into $G_{s \alpha}$ was complete at $90 \mathrm{~min}$ in sarcolemma from both normal and failing LV, after which no further incorporation was seen (data not shown, see reference 4). During this time NAD concentrations were constant as demonstrated by polyethyleneimine-cellulose thin layer chromatography. Results of the second method are shown in the inset of Fig. 1. Membranes were first treated with cholera toxin as described in Methods except that either no NAD (Fig. $1 A$ ) or $5 \mu \mathrm{M}$ unlabeled NAD (Fig. $1 B$ ) was substituted for $\left[{ }^{32}\right.$ P]NAD. Both membrane samples were then washed extensively and again treated with cholera toxin for 90 min as described in Methods using $5 \mu \mathrm{M}\left[{ }^{32} \mathrm{P}\right] \mathrm{NAD}$. Inset $A$ shows the usual pattern of cholera toxin labeling, whereas inset $B$ shows almost no labeling. When the bands were excised and counted, $B$ contained $<5 \%$ of the radiolabel seen in $A$, indicating that $>95 \%$ of all available $\mathrm{G}_{\mathrm{s} \alpha}$ was labeled under these conditions. When this method was used to assess levels of $\mathrm{G}_{\mathrm{s} \alpha}$, a $59 \%$ reduction $(P<0.005)$ was seen in sarcolemma derived from failing $\mathrm{LV}$ when compared with normal control sarcolemma as demonstrated by the bar graph in Fig. 1 .

Reconstitution of $G_{s}$. Activity of $\mathrm{G}_{\mathbf{s}}$ was also assessed using a reconstitution assay originally described by Sternweis and co-workers (15). Briefly, the technique makes use of the fact that $G_{s}$ can be solubilized from sarcolemmal membranes and then functionally coupled to $c y c-\mathrm{S} 49$ mouse lymphoma cell membranes. The $c y c$ - cell line was originally described by Bourne et al. (19) and is functionally deficient in $G_{s}$, but has adenylate cyclase catalytic unit. Therefore, there was essen- tially no measurable adenylate cyclase activity in $c y c$ - membranes before reconstitution with $\mathrm{G}_{\mathbf{s}}$. After $c y c$ - membranes are reconstituted with $G_{s}$, adenylate cyclase activity is restored, in proportion to the amount of reconstituted $G_{s}$. Adenylate cyclase was stimulated in the reconstituted membrane using sodium fluoride, which activates adenylate cyclase via $G_{s}$. Fig. 2 shows the ability of $G_{s}$ from sarcolemma from failing and normal $\mathrm{LV}$ to reconstitute $c y c$ - adenylate cyclase over a range of added sarcolemma protein. The curves are linear, so that reconstituted activity, reflecting the amount of $G_{s}$, is directly proportional to the amounts of added sarcolemma. For any amount of sarcolemma within the linear range, there was a decrease of $\sim 50 \%$ in the reconstituting activity of sarcolemma derived from failing $L V$ when compared with normal controls. These data indicate that $\mathrm{G}_{\mathrm{s}}$ was reduced by $50 \%$ in the failing LV when compared with controls and are in agreement with the measurement of $G_{s}$ using cholera toxin.

When larger amounts of sarcolemma from normal and failing LV were used in the reconstitution assay (Fig. 3), the curves became nonlinear as reconstituted $\mathrm{G}_{\mathrm{s}}$ began to saturate the catalytic unit of adenylate cyclase provided by $c y c$ - The data were modelled using least squares analysis to MichaelisMenten curves, with $r^{2}>0.95$ in each case. The curves predict different maximum activities for reconstituted $G_{s}$ from normal and failing LV. These data indicate that the $V_{\max }$ for hydrolysis of ATP to cAMP of the complex formed from $\mathrm{G}_{\mathrm{s}}$ from failing left ventricle and $c y c$ - catalytic unit may be less than that formed from $c y c$ - catalytic unit and $G_{s}$ donated from normal hearts. One possibility is that the $G_{s}$ from failing ventricle is qualitatively different from $\mathrm{G}_{\mathrm{s}}$ from normal ventricle. Further studies are needed to address this possibility.

Although the cholera toxin and reconstitution data were concordant in that they showed a $50-60 \%$ reduction in $\mathrm{G}_{\mathrm{s}}$ content and activity in failing left ventricle, we wanted to ensure that the decrease in activity of $G_{s}$ as demonstrated by reconstitution studies was not due to the co-reconstitution of an inhibitor. This possibility was addressed in the following

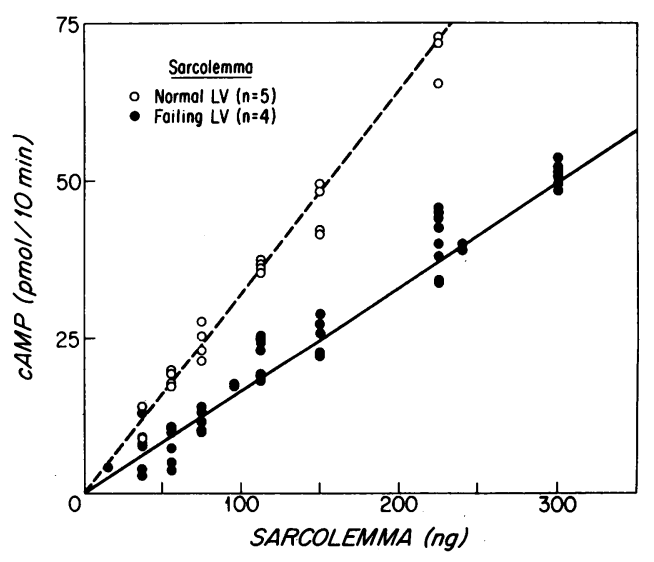

Figure 2. Reconstitution of $\mathrm{G}_{\mathbf{s}}$ from sarcolemma into $c y c$-. Solubilized sarcolemma were reconstituted into a fixed amount of $c y c$ membrane, and adenylate cyclase activity, stimulated by $\mathrm{NaF}$, was measured. In the range where reconstituted adenylate cyclase activity is a linear function of the amount of sarcolemma added to each assay, a 50\% reduction of activity was seen in assays using sarcolemma from failing LV when compared with normals. The data are from two experiments each with duplicate points for each animal at each sarcolemma concentration. 


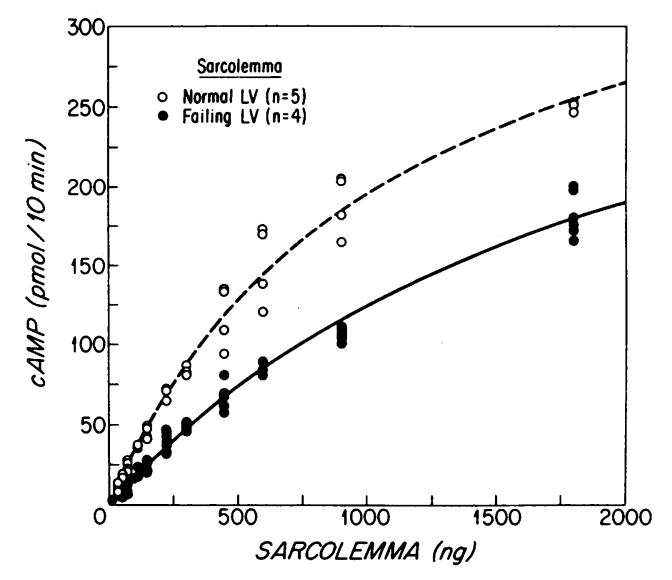

Figure 3. When a broader range of amounts of sarcolemma are reconstituted into a fixed amount of $c y c$-, the curves become nonlinear as reconstituted $\mathrm{G}_{\mathbf{s}}$ saturates $c y c$ - catalytic unit of adenylate cyclase and can be modeled to a Michaelis-Menten function. The model curves "plateau" at different values (normal, 412 pmol cAMP/10 min; LV failure, 376 pmol cAMP/10 min).

manner. Equal quantities of sarcolemma from normal and failing hearts were mixed, and reconstituted adenylate cyclase activity was measured. This was compared with the reconstituted activity from either sarcolemma alone. Fig. 4 shows the results of this experiment. The activities contributed by the sarcolemma from normal and failing left ventricle were additive, suggesting that only a stimulatory component is assayed in these experiments, and that an inhibitory species does not account for the results seen in Figs. 2 and 3.

\section{Discussion}

The molecular pathogenesis of decompensation of the hypertrophied left ventricle remains a central question in cardiovascular physiology. The canine model employed in these studies affords an opportunity to study this problem because it mimics a common syndrome seen in man, namely gradual chronic

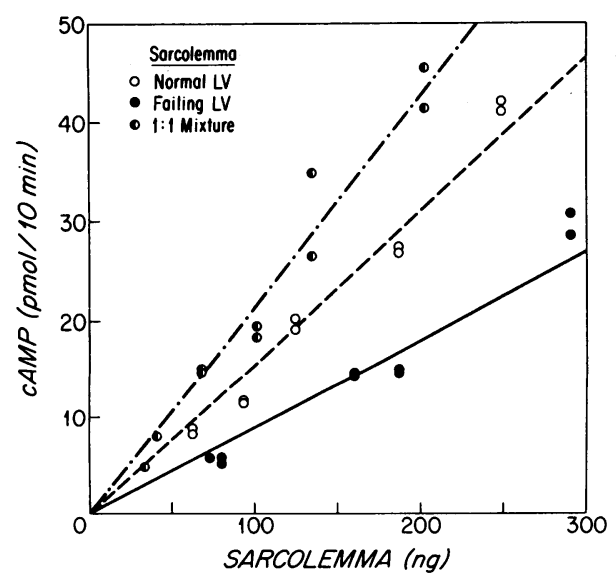

Figure 4. Solubilized sarcolemma from one normal and one failing left ventricle were reconstituted as in Fig. 2. In addition, mixtures of equal amounts (the total amount is twice that indicated on the abscissa) of each were also reconstituted into $c y c$-. This curve is approximately the sum of the first two. pressure overload of the left ventricle due to systemic hypertension, causing myocardial hypertrophy and then failure. We have shown that $\mathrm{G}_{\mathrm{s}}$, a component of the left ventricular membranes that is necessary to transduce the inotropic effects of catecholamines, is defective and/or deficient in the failing left ventricle. Because the failing heart is dependent on adrenergic drive to maintain and increase cardiac output (1), defects in this transduction mechanism would be expected to affect the ability of the hypertrophied heart to maintain the enhanced contractile state necessary in the setting of a persistently elevated ventricular pressure. It is then possible that an acquired defect in $G_{s}$, as we have described here, is responsible for hyporesponsiveness of the hypertrophied, failing left ventricle to adrenergic stimulation. Such a defect could therefore contribute to myocardial decompensation and the clinical syndrome of heart failure.

Bristow and co-workers (5) studied myocardial $\beta$-adrenergic receptors in explanted hearts from patients who underwent cardiac transplantation because of ischemic or idiopathic cardiomyopathy. The failing hearts had a 50\% reduction in these receptors in comparison with normal controls. The authors also showed decreased inotropic responsiveness of ventricular tissue in response to $\beta$-adrenergic stimulation and suggested that this was due to the decrease in receptor density. We have demonstrated an increase in left ventricular $\beta$-adrenergic receptors in our animal model, as have Karliner et al. (3), who used a guinea pig model of heart failure. The differences in receptor density between these studies may be due to many factors. These include differences in the etiologies of left ventricular failure, in species, in the state of left ventricular compensation, and, potentially, in prior therapy. It is important to emphasize that our data from this animal model indicate that the density of $\beta$-adrenergic receptors in the failing left ventricle actually increased as assessed by antagonist binding studies, whereas $G_{s}$ activity decreased by $50-60 \%$. It is likely that changes in $G_{s}$ account for the reduced adenylate cyclase activity previously reported by this laboratory (4).

Our data are also relevant to the pathophysiologic mechanisms of noncardiac disease as well. Bourne (20), Spiegel (21), and their co-workers have described a genetically determined deficiency in $G_{s}$ in patients with type Ia pseudohypoparathyroidism. Because of this deficiency, parathyroid hormone receptors that are coupled to $G_{s}$ are unable to activate distal effector mechanisms properly. The $\beta$-adrenergic receptorstimulated adenylate cyclase activity in tissues from these patients is also depressed because $\mathrm{G}_{\mathrm{s}}$ couples the $\beta$-adrenergic receptor to adenylate cyclase. Heinsimer et al. (22) have shown that a $50 \%$ reduction in $\mathrm{G}_{\mathrm{s}}$ in erythrocyte membranes from these patients (as demonstrated by reconstitution studies) could account for a reduction from 50 to $10 \%$ in the fraction of $\beta$-adrenergic receptor agonist high-affinity sites. Our previous studies (4) and the present data show a similar finding: a 50\% reduction in $\mathrm{G}_{\mathbf{s}}$ (acquired in our model rather than genetically determined) was accompanied by the same reduction in $\beta$-receptor agonist high-affinity sites.

Our understanding of the function of $G$ proteins in the molecular mechanisms of transmembrane signal transduction is still incomplete. It is clear that this family of proteins is relevant in many mechanisms of hormonal and neural signaling. $\mathrm{G}_{\mathrm{s}}$ not only couples the $\beta$-adrenergic receptor to adenylate cyclase but also couples many peptide and prostaglandin receptors to their intracellular effectors (6). Other members of 
this family of proteins are likely to play central roles in the regulation of ion fluxes across cell membranes as well (23). Given the broad range of effector mechanisms coupled to $G$ proteins, an acquired defect in one or more of these proteins may be causally related to the molecular mechanism(s) responsible for decompensation of the hypertrophied heart. The model of altered $\mathrm{G}$ protein function which we have described here offers an excellent opportunity to investigate these processes at the level of protein chemistry as well as that of molecular biology. Whether loss in $\mathrm{G}_{\mathbf{s}}$ activity in this animal model of heart failure represents a quantitative decrease in the level of this protein or a qualitative change owing to a transcriptional or posttranslational modification $(24,25)$ will require further investigation.

\section{Acknowledgments}

The authors would like to thank Drs. Elliott Ross, Paul Sternweis, and Robert Graham for their helpful advice, and Ms. Edythe Scott for her assistance in the preparation of this manuscript.

D. Vatner was supported by the American Heart Association, Massachusetts affiliate, grant No. 13-518-856. C. Homcy (HL-19259) and S. Vatner (HL-38070, HL-33743, and RR-00168) were supported by the National Institutes of Health, Heart, Lung, and Blood Institute.

\section{References}

1. Covell, J. W., C. A. Chidsey, and E. Braunwald. 1966. Reduction of cardiac response to postganglionic nerve stimulation in experimental heart failure. Circ. Res. 19:51-56.

2. Spann, J. F., C. A. Chidsey, P. E. Pool, and E. Braunwald. 1965. Mechanisms of norepinephrine depletion in experimental heart failure produced by aortic constriction in the guinea pig. Circ. Res. 17:312321.

3. Karliner, J., P. Barnes, M. Brown, and C. Dollery. 1980. Chronic heart failure in the guinea pig increases cardiac alpha-1 and beta-adrenoceptors. Eur. J. Pharmacol. 67:115-118.

4. Vatner, D. E., S. F. Vatner, A. M. Fujii, and C. J. Homcy. 1985. Loss of high affinity cardiac beta-adrenergic receptors in dogs with heart failure. J. Clin. Invest. 76:2259-2264.

5. Bristow, M. R., R. Ginsburg, W. Minobe, R. S. Cubicciotti, W. S. Sagerman, K. Lurie, M. E. Billingham, D. C. Harrison, and E. B. Stinson. 1982. Decreased catecholamine sensitivity and $\beta$-adrenergicreceptor density in failing human heart. N. Engl. J. Med. 307:205-211.

6. Longabaugh, J. P., D. E. Vatner, and C. J. Homcy. 1986. The beta-adrenergic receptor/adenylate cyclase system. In The Heart and Cardiovascular System. H. A. Fozzard, E. Haber, R. B. Jennings, A. M. Katz, and H. E. Morgan, editors. Raven Press, New York. 1097-11 18.

7. Gilman, A. G. 1984. Guanine nucleotide-binding regulatory proteins and dual control of adenylate cyclase. J. Clin. Invest. 73:1-4.

8. Vatner, D. E., C. J. Homcy, S. P. Sit, W. T. Manders, and S. F. Vatner. 1984. Effects of pressure overload, left ventricular hypertrophy on $\beta$-adrenergic receptors, and responsiveness to catecholamines. $J$. Clin. Invest. 73:1473-1482.

9. Schramm, M., and Z. Selinger. 1984. Message transmission: receptor controlled adenylate cyclase system. Science (Wash. DC). 225:1350-1356.

10. Kleinman, L. H., A. S. Wechsler, J. C. Rembert, J. M. Fedor, and J. C. Greenfield, Jr. 1978. A reproducible model of moderate to severe concentric left ventricular hypertrophy. Am. J. Physiol. 234(Suppl. 3):h515-h524.

11. Knight, D. R., D. A. Kirby, and S. F. Vatner. 1985. Effects of a calcium channel blocker on cardiac output distribution in conscious hypertensive dogs. Hypertension (Dallas). 7:380-385.

12. Jones, L. R., and H. R. Besch, Jr. 1984. Isolation of canine cardiac sarcolemmal vesicles. Methods Pharmacol. 5:1-12.

13. Longabaugh, J. P., D. E. Vatner, R. M. Graham, and C. J. Homcy. 1986. NADP improves the efficiency of cholera toxin catalyzed ADP-ribosylation in liver and heart membranes. Biochem. Biophys. Res. Commun. 137:328-333.

14. Laemmli, U. K. 1970. Cleavage of structural proteins during the assembly of the head of bacteriophage T4. Nature (Lond.). 227:680-685.

15. Sternweis, P. C., J. K. Northrup, M. D. Smigel, and A. G. Gilman. 1981. Regulatory component of adenylate cyclase; purification and properties. J. Biol. Chem. 256:11517-11526.

16. Lowry, O. H., N. J. Rosebrough, A. L. Fart, and R. J. Randall. 1951. Protein measurement with Folin phenol reagent. J. Biol. Chem. 193:265-275.

17. Ross, E. M., M. E. Maguire, T. W. Sturgill, R. L. Biltonen, and A. G. Gilman. 1978. Relationship between the $\beta$-adrenergic receptor and adenylate cyclase. J. Biol. Chem. 252:5761-5775.

18. Moss, J., and M. Vaughn. 1979. Activation of adenylate cyclase by choleragen. Annu. Rev. Biochem. 48:581-600.

19. Bourne, H. R., P. Coffino, and G. M. Tomkins. 1975. Selection of a variant lymphoma cell deficient in adenylate cyclase. Science (Wash. DC). 18:750-752.

20. Farfel, Z., A. S. Brickman, H. R. Kaslow, V. M. Brothers, and H. R. Bourne. 1980. Defect of receptor-cyclase protein coupling in pseudohypoparathyroidism. N. Engl. J. Med. 303:237-242.

21. Levine, M. A., R. W. Downs, Jr., M. Singer, S. J. Marx, G. D. Aurbach, and A. M. Spiegel. 1980. Deficient activity of guanine nucleotide regulatory protein in erythrocytes from patients with pseudohypoparathyroidism. Biochem. Biophys. Res. Commun. 94:13191324.

22. Heinsimer, J. A., A. O. Davies, R. W. Downs, M. A. Levine, A. M. Spiegel, M. K. Drezner, A. DeLean, K. A. Wregget, M. G. Caron, and R. J. Lefkowitz. 1984. Impaired formation of $\beta$-adrenergic receptor-nucleotide binding protein complexes in pseudohypoparathyroidism. J. Clin. Invest. 68:1450-1455.

23. Martin, J. M., D. D. Hunter, and N. M. Nathanson. 1985. Islet activating protein inhibits physiological responses evoked by cardiac muscarinic acetylcholine receptors. Role of guanosine triphosphate binding proteins in regulation of potassium permeability. Biochemistry. 24:7521-7525.

24. Bray, P. A., A. Carter, C. Simons, V. Guo, C. Puckett, J. Kamholz, A. Spiegel, and M. Nirenberg. 1986. Human cDNA clones for four species of $\mathrm{G}_{\mathrm{s \alpha}}$ signal transduction protein. Proc. Natl. Acad. Sci. USA. 83:8893-8897.

25. Robishaw, J. D., M. D. Smigel, and A. G. Gilman. 1986. Molecular basis for two forms of the $G$ protein that stimulate adenylate cyclase. J. Biol. Chem. 261:9587-9590. 